\title{
HAK AKSES KESEHATAN MASYARAKAT TERHADAP HAK PATEN PRODUK FARMASI
}

\author{
Raden Bagoes Prasetyo Raharjo, Kholis Roisah \\ Fakultas Hukum Universitas Diponegoro, Semarang \\ agunglarasati88@gmail.com
}

\begin{abstract}
Abstrak
Mengingat pentingnya kerjasama global dalam pengembangan obat untuk mengatasi Covid-19, para produsen obat nasional masih menemui berbagai masalah. Hak paten menjadi tantangan utama produsen obat nasional. Ancaman paten terhadap kesehatan masyarakat, khususnya di berbagai negara terbelakang, adalah isu yang sudah lama. Para anggota WTO sudah sepakat dengan perlindungan paten obat masuk dalam agenda WTO. Bagi negara-negara berkembang dan terbelakang hal tersebut masih menjadi perdebatan yang serius. Dasar dari penelitian ini adalah untuk mengetahui perlindungan paten obat berdasarkan ketentuan perjanjian TRIPS dan mekanisme pengajuan hak paten obat virus Corona ketika dalam keadaan yang darurat. Metode penelitiannya menggunakan yuridis normatif. Hasil penelitian menunjukkan perlindungan paten obat berdasarkan ketentuan perjanjian TRIPS terhadap hak ases kesehatan masyarakat dapat dilakukan yakni dengan impor paralel, bolar provision, lisensi wajib, dan pemakaian paten obat pemerintah. Implementasi paten bagi negara Indonesia sudah tertuang dalam UU Paten No. 13 Tahun 2016. Mekanisme pengajuan hak paten obat virus Corona dalam keadaan darurat dapat dilakukan berdasar aturan Perjanjian TRIPs Pasal 31, memungkinkan bagi sebuah negara untuk membuat pengajuan lisensi wajib ataupun government use, terutama pada kondisi genting sehingga berkemungkinan adanya penerapan paten tanpa seizin dari pemilik patennya.
\end{abstract}

Kata kunci: Covid-19; Farmasi; Kesehatan; Paten

\section{COMMUNITY HEALTH ACCESS RIGHTS TO PATENT RIGHTS OF PHARMACEUTICAL PRODUCTS}

\begin{abstract}
Given the importance of global cooperation in drug development to overcome Covid-19, national drug manufacturers are still facing various problems. Patent rights are a major challenge for national drug manufacturers. The threat of patents to public health, particularly in underdeveloped countries, is a longstanding issue. The WTO members have agreed that the protection of drug patents is included in the WTO agenda. For developing and underdeveloped countries, this is still a serious debate. The basis of this research is to determine the protection of drug patents based on the provisions of the TRIPS agreement and the mechanism for filing a Coronavirus drug patent when in an emergency situation. The research method uses normative juridical. The results show that the protection of drug patents based on the provisions of the TRIPS agreement on public health access rights can be carried out, namely by parallel import, spherical provision, mandatory licensing, and the use of government drug patents. The implementation of patents for the Indonesian state has been stated in the Patent Law no. 13 of 2016. The mechanism for filing a patent for a Coronavirus drug in an emergency can be carried out based on the provisions of the TRIPs Agreement Article 31, it is possible for a country to apply for a mandatory license or government use, especially in critical conditions so that it is possible to apply a patent without the permission of the patent owner.
\end{abstract}

Keywords: Covid-19; Pharmacy; Health; Patent 


\section{A. PENDAHULUAN}

Ketika negara terserang suatu wabah penyakit dan menimbulkan kedaruratan kesehatan masyarakat dalam sebuah negara, permasalahan yang besar akan terjadi jika harga produk farmasinya yang tinggi. ${ }^{1}$ Perdagangan obat melalui kebijakan paten, yang berkaitan dengan TRIPS mengakibatkan negara terbatas dalam mengembangkan farmasi, khususnya dalam membuat obat generik, yakni obat yang dibuatnya sesudah masa patennya berakhir. Paten sangat berpengaruh terhadap harga sebab terdapat monopoli kepemilikan dan harus membayar royalti pada pemilik hak patennya, seperti aturan harga jual obat dan dimanakah obat tersebut akan disalurkan. Dengan begitu paten dapat mengganggu akses pasien terhadap obat. ${ }^{2}$

Indonesia sangat kaya dengan keragaman hayati yang tersebar di berbagai wilayah, keanekaragaman tersebut terbagi menjadi 3 yakni tingkat genetik, spesies dan ekosistem. ${ }^{3}$ Keragaman tersebut tersebar di berbagai wilayah Indonesia dan bisa dipergunakan menjadi obat tradisional untuk mencegah penyakit, menyebuhkan, memulihkan kesehatan serta peinigkatan kesehatan masyarakat. WHO (World Health Organization) sudah mengesahkan pemanfaatan obat tradisional dalam upaya memelihara kesehatan, mencegah ataupun mengobati penyakit di masyarakat. Keputusan WHO yang mengesahkan penggunaan obat tersebut memberikan keuntungan bagi negara Indonesia terkait dengan pengembangan obat tradisional. Mengingat Indonesia begitu potensial dalam hal obat tradisional maka penting adanya sebuah penelitian yang memadai guna menunjang penemuan-penemuan baru di bidang pengetahuan tradisional yang bisa memberikan keuntungan seluruh pihak terutama masyarakat dan negara.

Pemahaman masyarakat yang minim tentang HKI akan dimanfaatkan oleh negara yang industri farmasinya maju untuk diambil keuntungan dari pemhamaman obat tradisional tanpa izin dan kompensasi pada masyarakat pemiliknya.. ${ }^{4}$ Obat paten ialah subset dari HKI yakni tergolong dalam kategori hak kekayaan perindustrian. Indonesia sudah 4 kali mengalami perubahan kebijakan terkait dengan paten yakni UU No. 6 Tahun 1989 mengalami perubahan menjadi UU No. 1 Tahun 1997, mengalami perubahan dengan UU No. 14 Tahun 2001 dan yang terbaru adalah UU No. 13 Tahun 2016.5 .

Khusus bagi negara terbelakang, ancaman paten terhadap kesehatan publik bukan sebuah isu baru. Hal tersebut senantiasa menjadi tema populer yang dibahas di level internasional. Perlindungan paten obat yang sudah menjadi kesepakatan oleh

${ }^{1}$ Irawati Yustisiana Susila Atmaja, Budi Santoso, "Pelindungan Hukum Terhadap Paten Produk Farmasi Atas Pelaksanaan Paten Oleh Pemerintah (Government Use).," Masalah-Masalah Hukum 50, no. 2 (2021): 196, https://doi.org/http://dx.doi.org/10.14710/mmh.50.2.2021.196-208.

${ }^{2}$ Creata.id, "Paten Obat, Akses Masyarakat, Dan Pengembangan Industri Farmasi," 2017, https://www.creata.or.id/1904-2/.

${ }^{3}$ Miranda Risang Ayu, Hukum Sumber Daya Genetic, Pengetahuan Tradisional Dan Ekspresi Budaya Tradisional Di Indonesia, (Bandung: PT Alumni, 2014).

${ }^{4}$ Trias Palupi Kurnianingrum, "Pelindungan Hak Paten Atas Pengetahuan Obat Tradisional Melalui Pasal 26 UU No. 13 Tahun 2016 Tentang Paten,” Jurnal Negara Hukum 10, no. 1 (2019).

${ }^{5}$ Lidya Shery Muis, "Hak Atas Aksesibilitas Obat Paten Bagi Masyarakat," Pranata 2, no. 1 (2019): 37, https://doi.org/https://doi.org/10.37631/widyapranata.v1i1.259. 
negara WTO untuk dituliskan dalam agendanya WTO, sebagai suatu tema yang masih terjadi polemik di negara berkembang dan terbelakang. Sepanjang 16 tahun setelah pemberlakuan efektif di sejumlah negara, masalah yang muncul dikarenakan perlindungan paten banyak ditemui di sejumlah negara berkembang dan terbelakang. Dengan serentetan penelitian yang intensif serta lebih dalam, sejumlah pakar menyepakati jika paten obat memiliki dampak pada harga obat dan ketersediaan obat generik.

Produsen vaksin di Indonesia masih memiliki beberapa masalah, ditengah pentingnya kerjasama global dalam pengembangan obat untuk menangani virus Corona, di antaranya ialah hak paten. Sejumlah kendala yang dialami produsen vaksin khususnya dari negara berkembang. Pertama, akses yang terbatas pada riset serta pengembangan vaksin baru dikarenakan negara maju telah berkoalisi dengan kuat. Yang kedua, adanya keterbatasan dalam hak paten.

Sebenarnya sewaktu wabah flu burung melanda, perusahaan juga merasakan masalah terkait dengan hak paten. Waktu itu, banyak sekali negara maju yang menyajikan hasil temuan dari industri farmasi. Tetapi hak paten untuk produksi tidak dibuka, untuk itu penemuan vaksin flu burung yang yang berhasil dikembangkan oleh negara berkembang tidak dapat terealisasikan. Di samping itu, alokasi dana di negara berkembang khususnya pada manufaktur farmasi juga sangat terbatas. ${ }^{6}$

Sebuah penelitian yang dilaksanakan oleh Sari (2019), memperlihatkan jika perlindungan pengetahuan tradisional dalam perspektif HKI masuk ke rezim paten yaitu Pasal 26 UU Paten, tetapi perlindungan atas obat tradisional terjadi kendala dikarenakan tidak sesuai persyaratan pada paten. Tindakan pemerintah dalam memberi perlindungan bisa berupa menyusun UU baru dan mendokumentasikan obat tradisional tradisional. ${ }^{7}$

Sebuah penelitian yang dilaksanakan oleh Wowiling (2017 menunjukkan hasil antara lain, Perlindungan hukum hak paten berupa ratifikasi dari TRIPs Agreement. Indonesia sudah meratifikasi WTO lewat UU No. 7 Tahun 1994 selaku konsekuensinya ratifikasi TRIPs maka Indonesia juga harus menyusun peraturan terkait HaKI yang merujuk dari TRIPs Agreement. UU No. 13 Tahun 2016 menjelaskan mengenai penegakan hukum hak paten sebagai pengganti UU Paten lama yakni UU Nomor 14 Tahun 2001. ${ }^{8}$

Sedangkan penelitian yang dilaksanakan oleh Kurnianingrum (2019) menyimpulkan yakni walaupun Perjanjian TRIPs belum mengakomodasikan pengetahuan tradisional tetapi adanya UU Paten 2016 mendukung upaya pemerintah Indonesia dalam penyelamatan pengetahuan obat tradisional dari biopiracy dan

\footnotetext{
${ }^{6}$ Nindya Aldila, “Hak Paten Jadi Kendala Produsen Vaksin Untuk Riset Obat Covid-19,” Kabar 24, 2020, Hak Paten Jadi Kendala Produsen Vaksin untuk Riset Obat Covid-19.

${ }^{7}$ Ni Komang Ayu Weda Sari, "Pengaturan Perlindungan Hukum Atas Obat Tradisional Berdasarkan Perspektif Hak Kekayaan Intelektual," Journal Ilmu Hukum 6, no. 2 (2019): 15, https://doi.org/<https://ojs.unud.ac.id/index.php/kerthasemaya/article/view/54349>.

${ }^{8}$ Rignaldo Ricky Wowiling, "Penegakan Hukum Hak Paten Menurut Trips Agreement Dan Pelaksanaanya Di Indonesia," Jurnal Laex Crimen 6, no. 10 (2017).
} 
misappropriation. Kewajiban disclosure pada Perjanjian TRIPs dan mekanisme selanjutnya perlu diatur terkait benefit sharing dan akses yang didapatkan terhadap pengetahuan obat tradisional. ${ }^{9}$

Dilakukan keperbaharuan pada penelitian ini dari penelitian sebelumnya. Maka tujuan penelitian ini adalah terkait perlindungan hak paten obat serta mekanisme pengajuan paten pada saat keadaan darurat seperti pada masa pandemi Covid-19 saat ini, sehingga didapatkan sebuah hasil baru yang menunjukkan pemecahan dari masalah dipenelitian yang sebelumnya.

\section{B. PERMASALAHAN}

1. Bagaimanakah perlindungan paten obat berdasarkan ketentuan perjanjian TRIPS terhadap hak ases kesehatan masyarakat?

2. Bagaimana mekanisme pengajuan hak paten obat virus Corona dalam keadaan darurat?

\section{METODE PENELITIAN}

Pada penyusunan jurnal ilmiah ini, penelitian normatif digunakan peneliti sebagai metode penelitiannya. Metode penelitian hukum ini dikonsepkan dalam perundangan ataupun norma yang menjadi dasar seseorang dalam berbuat. ${ }^{10}$. Penelitian yuridis normatif ialah dengan basis pada keilmuan hukum normative yang menelaah penerapan sistem aturan hukum positif dalam penerapannya dimasyarakat dengan mengkolaborasikan data dan realitas yang ada, biasanya penelitian ini dinamakan penelitian bekerjanya hukum (law in action). Inti kajiannya ialah penerapan aturan hukum positif dan kontrak secara faktual pada tiap kejadian hukum tertentu yang ada di masyarakat untuk meraih tujuan yang ditetapkan. ${ }^{11}$

\section{HASIL DAN PEMBAHASAN}

\section{Perlindungan Paten Obat Berdasarkan Ketentuan Perjanjian TRIPS Terhadap Hak Ases Kesehatan Masyarakat}

Paten ialah suatu cabang HKI yang memberi perlindungan pada temuan ataupun invensi baru di bidang teknologi. Paten memberi hak eksklusif pada pemegang hak untuk melakukan sendiri invensi dalam periode tertentu ataupun menyetujui pihak lainnya untuk melakukannya. Invensi yang bisa diberi paten ialah invensi di bidang teknologi yang baru, memuat tindakan inventif dan bisa direalisasikan di bidang industri. Paten selaku subset dari hak milik perindustrian diperuntukkan pada seluruh penemuan, yang berbentuk produk ataupun proses, di seluruh penemuan bidang teknologi selama penemuannya baru, menggunakan langkah inventif dan bisa diaplikasikan di bidang industri (Persetujuan TRIPs, Pasal 27). ${ }^{12}$ Pada hakikatnya

${ }^{9}$ Kurnianingrum, "Pelindungan Hak Paten Atas Pengetahuan Obat Tradisional Melalui Pasal 26 UU No. 13 Tahun 2016 Tentang Paten."

${ }^{10}$ Amirudin dan Zainal Askin, Pengantar Metode Penelitian Hukum (Jakarta: PT Raja Grafindo Persada, 2012).

${ }^{11}$ Galang Taufani Suteki, Metodologi Penelitian Hukum (Filsafat, Teori, Dan Praktik) (Depok: PT. Raja Grafindo Persada, 2018).

${ }^{12}$ Chandra Muliawan, "Pemberian Paten Obat-Obatan Dan Pemenuhan Hak Asasi Manusia Terhadap Kesehatan Di Indonesia," Jurnal Ilmu Hukum 14, no. 2 (2019): 208, https://doi.org/https://doi.org/10.36448/pranatahukum.v14i2.84. 
Perjanjian TRIPS sekedar menentukan standar minimal perlindungan HKI. Artikel 1.1 TRIPS secara jelas memberi kebebasan pada tiap anggota WTO untuk implementasi perlindungan HKI. ${ }^{13}$

Obat modern adalah salah satu contoh dari berbagai penemuan yang dapat dipatenkan. Banyaknya biaya yang digunakan dalam riset dan pengembangan (R\&D) ditanggung oleh produsen dalam memproduksi obat untuk menangani beragam penyakit. Paten terkait obat bersangkutan menjamin yakni biaya R\&D yang dibayarkan produsen bisa ditutupi dalam tempo perlindungan patennya (minimal 20 tahun). Dalam tempo perlindungan paten ini, pemegang paten ataupun produsen dari obat-obatan bersangkutan memiliki hak untuk membuat, menyalurkan, menggali secara ekonomis serta tidak membolehkan pihak lain yang tidak berizin untuk membuat obat-obatan bersangkutan.

Meskipun tujuannya baik memberi penghargaan terhadap sebuah penemuan, paten mempunyai dampak negatif menaikkan harga dan membatasi akses publik dari obat bersangkutan. Di level internasional, ancaman paten pada akses kesehatan public semakin riil sewaktu WTO memasukkan HKI selaku sebuah perjanjian yang harus dipatuhi oleh negara pengikutnya. Perjanjian TRIPs ialah perjanjian internasional di bawah administrasi WTO yang menentukan standar minimal untuk beragam aturan HKI, seperti paten, di tiap negara pesertanya. Implementasi TRIPs di seluruh negara anggota WTO memunculkan perdebatan sewaktu awal-awal dibentuknya TRIPs dikarenakan tingkat ekonomi dan pembangunan yang tidak sama antar Negara. ${ }^{14}$

Ada 12 pasal dalam perjanjian TRIPS yang berkaitan erat dengan perlindungan paten obat dan terdapat 3 pasal mengenai kebijakan dalam mengatasi efek paten obat yang biasa dinamakan pasal pelindung TRIPS. Sehubungan dengan adopsi pasal bersangkutan, peserta WTO hendaknya selalu konsisten dengan aturan yang ada dalam perjanjian TRIPs. Masalah yang biasa muncul ialah berhubungan dengan sifat dari TRIPs bersangkutan yang tidak ada standar hukum internasional ataupun syarat hukum yang sama bagi peserta WTO. Sehingga penerapan pasal pelindung bersangkutan, beserta bagaimanakah menafsirkan pasal bersangkutan tidak sama antar negara peserta WTO, terutama antar negara berkembang dengan yang maju. Ada 4 pasal pelindung TRIPs yang bisa dipergunakan untuk menangani efek buruk dari perlindungan paten ini, yakni impor paralel, bolar provision, lisensi wajib dan pemakaian paten oleh pemerintah.

\section{a.1 Impor paralel}

Merupakan suatu langkah importasi "tanpa persetujuan dari pemegang paten, dari sebuah produk yang dipasarkan di negara lain baik oleh pemegang paten maupun atas ijin dari pemegang paten." Penerapan impor paralel harus selaras dengan tata cara impor pada umumnya dan aturan terkait lain yang diberlakukan di

${ }^{13}$ Safril Sofwan Sanib, "Ketentuan-Ketentuan TRIPS-Plus Dalam Kerangka Perjanjian Perdagangan Bebas," Halu Oleo Law Review 3, no. 1 (2019): 50, https://doi.org/http://dx.doi.org/10.33561/holrev.v3i1.6016.

${ }^{14}$ UNIKA ATMAJAYA, "Hak Kekayaan Intelektual," 2020 , https://m.atmajaya.ac.id/web/KontenUnit.aspx? gid=artikel-hki\&ou=hki\&cid=ancaman-paten-terhadapkesehatan-publik-dan-safeguards-trips. 
suatu negara. Pada perjanjian TRIPs, dalam pasal 6 sudah dijelaskan secara luas terkait dengan importasi ini :

"For the purposes of dispute settlement under this Agreement, subject to the provisions of Articles 3 and 4 above nothing in this Agreement shall be used to address the issue of the exhaustion of intellectual property rights."

Pasal diatas mengelompokkan impor paralel selaku "pelepasan (exhaustion)" dari HKI dan tindakan pelepasan bersangkutan "bukan sebagai subjek dari proses penyelesaian sengketa WTO.” Doktrin penjualan pertama (first sale) dan hak-hak exhaustion merupakan dasar pembenaran impor paralel dalam konteks internasional. Pemilik HKI akan kehilangan berbagai hak kontrol atas barang yang sudah ia jual hal tersebut merupakan dasar dari doktrin first sale. Dari segi teoritis, dengan memposisikan barang bersangkutan di pasaran, pemilik melepas HKI atas barang yang dijualnya. Pada realitanya, adanya teori ini dapat memicu permasalahan dikarenakan tidak terdapat pembatasan secara jelas hingga seberapa jauh hak bersangkutan dilepaskannya.

a.2 Bolar provision

Ialah suatu kebijakan yang memberi ijin pada pihak eksternal untuk melakukan pengujian, pemakaian dan produksi obat yang masih mendapat perlindungan paten untuk kepentingan mendapat ijin edar dari pemegang kebijakan pengawasan obat dan makanan sebelum habis tempo perlindungan paten obatnya. Proses uji dan pemakaian serta produksi obat bersangkutan cuma sekedar untuk keperluan ijin edarnya saja, tidak untuk kepentingan komersial.

Karena bolar provision bisa menaikkan stok obat generik sesudah habis perlindungan paten dari suatu produk farmasi, sejumlah negara di dunia menyesuaikan dengan aturan bersangkutan pada hukum paten nasionalnya. Dari segi hukum, landasan pembenar atas diberlakukannya bolar provision ialah pada Pasal 30 perjanjian TRIPS:

"Members may provide limited exceptions to the exclusive rights conferred by a patent, provided that such exceptions do not unreasonably conflict with a normal exploitation of the patent and do not unreasonably prejudice the legitimate interests of the patent owner, taking account of the legitimate interests of third parties"

Pada pasal bersangkutan, perjanjian TRIPs bisa sebagai landasan hukum atas diberlakukannya bolar provision selama sesuai 2 syarat yakni pemberlakuannya tidak memicu konflik atas penggunaan paten yang normal serta tidak menimbulkan kerugian kepentingan yang legal dari pemegang patennya.

a.3. Lisensi wajib

Ialah "kewenangan yang diberikan oleh sebuah lembaga HKI atau otoritas administratif kepada pihak ketiga untuk menggunakan sebuah invensi yang dipatenkan tanpa persetujuan dari pemegang paten atas dasar kepentingan umum 
(paten yang tidak dilaksanakan, kesehatan masyarakat, praktek monopoli, keadaan darurat dan pertahanan nasional)."

Pasal 31 perjanjian TRIPS sebagai landasan hukum pemberlakuan lisensi wajib. Berdasar aturan pasal bersangkutan, pemakaian paten oleh pihak eksternal tanpa perizinan diperkenankan bila pemakaian paten bersangkutan sesuai sejumlah syarat baik dari permohonan awal untuk melakukan paten hingga memberi ganti rugi (royalti) yang layak kepada pemegang patennya.

\section{a.4. Penggunaan Paten Oleh Pemerintah}

Seperti pada lisensi wajib, pemakaian paten oleh pemerintah pun diperkenankan dalam perjanjian TRIPs lewat aturan yang ada pada Pasal 31. Seluruh syarat yang dibutuhkan untuk memberlakukan penggunaan paten ialah serupa dengan lisensi wajib, terkecuali persyaratan ijin awal dari pemegang patennya yang tidak dibutuhkan pada government use. Supaya sesuai dengan seluruh syarat perjanjian TRIPS, penerapan government use harus mempertimbangkan 3 syarat yakni: 1) dalam kodisi darurat nasional, atau 2) kondisi lain yang sifatnya mendesak, 3) penggunaan untuk kepentingan masyarakat dan sifatnya non-komersial.

\section{Mekanisme Pengajuan Hak Paten Obat Virus Corona Saat Kondisi Darurat}

Hingga saat ini vaksin dan obat yang dapat menangani virus Corona belum ditemukan. Tetapi sudah ada polemik mengenai hak paten atas vaksin dan obat bersangkutan dikarenakan sejumlah lembaga dan perusahaan farmasi mengutamakan hak ekonomi daripada untuk kesembuhan masyarakat di penjuru dunia. Walaupun tidak bisa dielakkan, bagi sebuah perusahaan farmasi perlindungan paten vaksin dan obat virus Corona sangatlah penting. Karena dalam mengembangkan dan menguji percobaan obat atau vaksin membutuhkan banyak sekali investasi dan waktunya yang panjang bagi dalam penelitiannya.

Sejumlah perusahaan farmasi bersaing mendaftarkan hak paten obat Corona. Kehadirannya menimbulkan pro dan kontra dikarenakan dipandang mengutamakan hak ekonomi. Pasalnya, berbicara tentang kekayaan intelektual yang menjadi tugas Kemenkumham ini tidak sekedar terkait perlindungan karya ataupun ciptaan, namun juga pada eksklusifitas dan hak ekonomi. Beberapa mempercayai bahwa obat virus Corona harus disediakan untuk orang banyak jadi sifat eksklusifnya sebagai bentuk dari konsekuensi patennya belumlah amat diperlukan. Tetapi perlindungan paten obat virus Corona juga dipandang sangat penting untuk perusahaaan farmasi, terlebih dalam mengembangkan dan menguji cobakan atas obat atas vaksin membutuhkan banyak investasi dan waktunya pihak peneliti.

Supaya vaksin ataupun obat Corona secepatnya dibuat massal, paten dapat melalui lisensi wajib ataupun penerapan paten oleh pemerintah. Berdasar aturan Perjanjian TRIPs Pasal 31, memungkinkan bagi sebuah negara untuk membuat 
pengajuan lisensi wajib ataupun government use, terutama pada kondisi genting sehingga berkemungkinan adanya penerapan paten tanpa seizin dari pemilik patennya.

Dalam konvensi internasional sudah menyetujui sistem perlindungan paten pada hukum nasional sebagai landasan dukungan pada sistem perlindungan. Dukungan bersangkutan sebagai penyesuaian hukum nasional dengan konvensi internasional. Sehingga akan ada perlindungan hukum yang sama antar negara yang menandatangani konvensi internasional terkait HAKI.

Pemberian perlindungan paten dilakukan sesudah paten tersebut deregister, pemberian paten ini sesuai permohonan. Berdasar aturan UU tiap HAKI harus diregister. Pendaftaran yang sesuai dengan syarat UU sebagai pengakuan pembenaran atas HAKI yang ditunjukkan dengan sertifikat pendaftaran sehingga mendapat perlindungan hukum. ${ }^{15}$ Perlindungan HAKI dikarenakan kewajiban register dinamakan dengan sistem konstitutif. Berdasar sistem konstitutif, HAKI individu mendapat pengakuan dan perlindungan dari UU jika diregister. Tidak diregister artinya tidak dilindungi dan diakui. Sistem konstitutif yakni dianut oleh UU No. 13 Tahun $2016 .{ }^{16}$

UU Paten No. 13 Tahun 2016 merupakan penerapan paten bagi pemerintah Indonesia. Pemerintah bisa melakukan paten tanpa perizinan dari pemegang paten pada kondisi darurat. Seperti dalam membuat produk farmasi ataupun bioteknologi dengan harga tinggi ataupun dibutuhkan dalam menangani penyakit yang bisa menimbulkan adanya kematian secara tiba-tiba dalam jumlahan yang banyak, menyebabkan cacat yang bermakna dan sebagai KKMMD.

Sehingga, penemu obat tetap memperoleh hak ekonominya dan ciptaanya mendapat perlindungan. Dede Mia Yusanti selaku pejabat Kemenkumham yang menjabat Direktur Paten, DTLST dan Rahasia Dagang, mengungkapkan yakni registrasi hak paten harus sesuai proses yang diberlakukan. Tiap pemohon harus sesuai syarat dan proses yang ada, yakni pengecekan formalitas, pengumuman, dan pengecekan substantif harus dijalankan. Ia menitikberatkan perlindungan paten bermula semenjak pemohon patennya mendapat tanggal penerimaan, walaupun pemberian patennya akan direalisasi sesudah proses. ${ }^{17}$

Pemohon dimungkinkan untuk meminta percepatan pengumuman agar dalam proses dari pengajuan hingga akhir pemeriksaannya bisa berlangsung lebih cepat, hal tersebut berdasarkan undang-undang yang berlaku. Tetapi aturan tersebut diberlakukan untuk umum bukan sebatas pada kondisi darurat.

Di negara Indonesia, hingga saat ini sama sekali belum ada pendaftaran paten obat atau vaksin mengenai Corona yang diregisterkan. Sedangkan bahan dari formula BCL, yang bisa dinyatakan dapat mencegah Corona sudah dilakukan pengajuan paten di DJKI. Tetapi hal tersebut tidak lantas menjadikan formula bersangkutan dapat

\footnotetext{
${ }^{15}$ Zaeni Asyhadie, Hukum Bisnis Prinsip Dan Pelaksanaannya (Jakarta: PT RajaGrafindo Persada, 2012).

${ }^{16}$ Valentino M Demmassabu, "Penghapusan Lisensi Paten Oleh Pemegang Hak Paten Menurut UndangUndang Nomor 13 Tahun 2016 Tentang Paten," Lex Privatum Jurnal 5, no. 2 (2017).

17 Ditjen Kekayaan Intelektual, "Paten Dan Rahasia Dagang," 2020, https:/www.dgip.go.id/tentangdjki/profil-pejabat?bagian=paten-dtlst-dan-rahasia-dagang-24.
} 
dipergunakan menangani penderita Covid-19. Tiap formulasi obat yang berlainan dari formula sebelumnya, baru bisa dipakai manusia sesudah mendapat izin edar penggunaan oleh otoritas terkait. DJKI cuma sebatas memberi perlindungan paten dikarenakan kriteria patentabilitas. Akan tetapi supaya bisa dipakai pada orang, harus dinilai efikasi, toksisitas dan keamanan sebagai kewenangannya BPOM. Website www.dgip.go.id merupakan layanan yang disediakan oleh Ditjen Kekayaan Intelektual untuk melayani registrasi paten dan kekayaan intelektual di masa pandemi Corona, dan paten.dgip.go.id merupakan layanan yang khusus disediakan bagi masyarakat. ${ }^{18}$

\section{E. PENUTUP}

Perlindungan paten obat berdasarkan ketentuan perjanjian TRIPS terhadap hak ases kesehatan masyarakat dapat dilakukan yakni dengan pertama, impor paralel yaitu merupakan suatu langkah importasi "tanpa persetujuan dari pemegang paten, dari sebuah produk yang dipasarkan di negara lain baik oleh pemegang paten maupun atas ijin dari pemegang paten.” Kedua, bolar provision ialah suatu kebijakan yang memberi ijin pada pihak eksternal untuk melakukan pengujian, pemakaian dan produksi obat yang masih mendapat perlindungan paten untuk kepentingan mendapat ijin edar dari pemegang kebijakan pengawasan obat dan makanan sebelum habis tempo perlindungan paten obatnya. Proses uji dan pemakaian serta produksi obat bersangkutan cuma sekedar untuk keperluan ijin edarnya saja, tidak untuk kepentingan komersial. Ketiga, lisensi wajib yaitu "kewenangan yang diberikan oleh sebuah lembaga HKI atau otoritas administratif kepada pihak ketiga untuk menggunakan sebuah invensi yang dipatenkan tanpa persetujuan dari pemegang paten atas dasar kepentingan umum (paten yang tidak dilaksanakan, kesehatan masyarakat, praktik monopoli, keadaan darurat dan pertahanan nasional)." Keempat, pemakaian paten obat pemerintah seluruh syarat yang dibutuhkan untuk memberlakukan penggunaan paten ialah serupa dengan lisensi wajib, terkecuali pesryaratan ijin awal dari pemegang patennya yang tidak dibutuhkan pada government use. Mekanisme pengajuan hak paten obat virus Corona dalam keadaan darurat dapat dilakukan berdasar aturan Perjanjian TRIPs Pasal 31, memungkinkan bagi sebuah negara untuk membuat pengajuan lisensi wajib ataupun government use, terutama pada kondisi genting sehingga berkemungkinan adanya penerapan paten tanpa seizin dari pemilik patennya supaya vaksin ataupun obat Corona secepatnya dibuat massal. UU Paten No. 13 Tahun 2016 merupakan penerapan paten bagi pemerintah Indonesia. Pemerintah bisa melakukan paten tanpa perizinan dari pemegang paten pada kondisi darurat.

\section{DAFTAR PUSTAKA}

Aldila, Nindya. "Hak Paten Jadi Kendala Produsen Vaksin Untuk Riset Obat Covid19.” Kabar 24, 2020. Hak Paten Jadi Kendala Produsen Vaksin untuk Riset Obat Covid-19.

Askin, Amirudin dan Zainal. Pengantar Metode Penelitian Hukum. Jakarta: PT Raja Grafindo Persada, 2012.

\footnotetext{
${ }^{18}$ Kumparan News, "Bagaimana Pengajuan Hak Paten Virus Corona Saat Kondisi Darurat,” 2020.
} 
Asyhadie, Zaeni. Hukum Bisnis Prinsip Dan Pelaksanaannya. Jakarta: PT RajaGrafindo Persada, 2012.

Atmajaya, Unika. "Hak Kekayaan Intelektual," 2020. https://m.atmajaya.ac.id/web/KontenUnit.aspx?gid=artikel-

hki\&ou=hki\&cid=ancaman-paten-terhadap-kesehatan-publik-dan-safeguardstrips.

Ayu, Miranda Risang. Hukum Sumber Daya Genetic, Pengetahuan Tradisional Dan Ekspresi Budaya Tradisional Di Indonesia,. Bandung: PT Alumni, 2014.

Creata.id. "Paten Obat, Akses Masyarakat, Dan Pengembangan Industri Farmasi," 2017. https://www.creata.or.id/1904-2/.

Demmassabu, Valentino M. "Penghapusan Lisensi Paten Oleh Pemegang Hak Paten Menurut Undang-Undang Nomor 13 Tahun 2016 Tentang Paten." Lex Privatum Jurnal 5, no. 2 (2017).

INTELEKTUAL, DITJEN KEKAYAAN. "Paten Dan Rahasia Dagang," 2020. https://www.dgip.go.id/tentang-djki/profil-pejabat?bagian=paten-dtlst-danrahasia-dagang-24.

Kurnianingrum, Trias Palupi. "Pelindungan Hak Paten Atas Pengetahuan Obat Tradisional Melalui Pasal 26 UU No. 13 Tahun 2016 Tentang Paten." Jurnal Negara Hukum 10, no. 1 (2019).

Muis, Lidya Shery. "Hak Atas Aksesibilitas Obat Paten Bagi Masyarakat." Pranata 2, no. 112019$)$ : 37. https://doi.org/https://doi.org/10.37631/widyapranata.v1i1.259.

Muliawan, Chandra. "Pemberian Paten Obat-Obatan Dan Pemenuhan Hak Asasi Manusia Terhadap Kesehatan Di Indonesia." Jurnal Ilmu Hukum 14, no. 2 (2019): 208. https://doi.org/https://doi.org/10.36448/pranatahukum.v14i2.84.

News, Kumparan. "Bagaimana Pengajuan Hak Paten Virus Corona Saat Kondisi Darurat," 2020.

Sanib, Safril Sofwan. "Ketentuan-Ketentuan TRIPS-Plus Dalam Kerangka Perjanjian Perdagangan Bebas." Halu Oleo Law Review 3, no. 1 (2019): 50. https://doi.org/http://dx.doi.org/10.33561/holrev.v3i1.6016.

Sari, Ni Komang Ayu Weda. "Pengaturan Perlindungan Hukum Atas Obat Tradisional Berdasarkan Perspektif Hak Kekayaan Intelektual.” Journal Ilmu Hukum 6, no. 2 (2019):

https://doi.org/<https://ojs.unud.ac.id/index.php/kerthasemaya/article/view/543 49>.

Suteki, Galang Taufani. Metodologi Penelitian Hukum (Filsafat, Teori, Dan Praktik). Depok: PT. Raja Grafindo Persada, 2018.

Wowiling, Rignaldo Ricky. "Penegakan Hukum Hak Paten Menurut Trips Agreement Dan Pelaksanaanya Di Indonesia.” Jurnal Laex Crimen 6, no. 10 (2017).

Yustisiana Susila Atmaja, Budi Santoso, Irawati. "Pelindungan Hukum Terhadap Paten Produk Farmasi Atas Pelaksanaan Paten Oleh Pemerintah (Government Use)." Masalah-Masalah Hukum 50, no. 2 (2021): 196. https://doi.org/http://dx.doi.org/10.14710/mmh.50.2.2021.196-208. 